\title{
COVID-19 Vaccine Prioritisation in Japan and South Korea
}

18 Seoul, 08826, South Korea

19 9 (1)

\footnotetext{
* Correspondence to:
}

\section{Yongdai Kim, Ph.D.}

${ }^{1}$ Department of Internal Medicine, National Cancer Center, Goyang, South Korea

${ }^{2}$ Department of Statistics, Seoul National University, Seoul, South Korea

${ }^{3}$ Faculty of Medicine and Health Sciences, University of Antwerp, Antwerp, Belgium

${ }^{4}$ Disease Control and Prevention Center, National Center for Global Health and Medici ne, Tokyo, Japan

${ }^{5}$ AMR Clinical Reference Center, National Center for Global Health and Medicine, To

$$
\text { kyo, Japan }
$$

$\dagger$ June Young Chun and Hwichang Jeong contributed equally to this manuscript.

Department of Statistics, Seoul National University, 56-1 Mountain, Sillim-dong, Gwanak-gu,

E-mail: ydkim0903@gmail.com, Tel: 82-2-880-9255; Fax: 82-2-883-6144 
medRxiv preprint doi: https://doi.org/10.1101/2021.04.16.21255649; this version posted April 20, 2021. The copyright holder for this preprint (which was not certified by peer review) is the author/funder, who has granted medRxiv a license to display the preprint in perpetuity.

It is made available under a CC-BY-NC-ND 4.0 International license.

20

21 Shinya Tsuzuki, MD, MSc.

22 Disease Control and Prevention Center, National Center for Global Health and Medici

23 ne, 1-21-1 Toyama, Shinjuku-ku, Tokyo, Japan

24 E-mail: stsuzuki@hosp.ncgm.go.jp, Tel: +81(0)3-3202-7181

25 


\section{Summary}

\section{Background}

28 Due to a limited initial supply of COVID-19 vaccines, the prioritisation of individuals for

29 vaccination is of utmost importance for public health. Here, we provide the optimal allocation

30 strategy for COVID-19 vaccines according to age in Japan and South Korea.

\section{Methods}

33 Combining national case reports, age-specific contact matrices, and observed periods

34 between each stages of infection (Susceptible-Exposed-Infectious-Quarantined), we

35 constructed a compartmental model. We estimated the age-stratified probability of

36 transmission given contact $\left(q_{i}\right)$ using Bayesian inference method and simulated different

37 vaccination scenarios to reduce either case numbers or death toll. We also performed

38 sensitivity analyses on the proportion of asymptomatic cases and vaccine efficacy.

\section{$40 \quad$ Findings}

41 The model inferred age-stratified probability of transmission given contact $\left(q_{i}\right)$ showed

42 similar age-dependent increase in Japan and South Korea. Assuming the reported COVID-19

43 vaccine efficacy, our results indicate that Japan and South Korea need to prioritise individuals

44 aged 20-35 years and individuals aged over 60 years, respectively, to minimise case numbers.

45 To minimise the death toll, both countries need to prioritise individuals aged over 75 years.

46 These trends were not changed by proportions of asymptomatic cases and varying vaccine 
medRxiv preprint doi: https://doi.org/10.1101/2021.04.16.21255649; this version posted April 20, 2021. The copyright holder for this preprint (which was not certified by peer review) is the author/funder, who has granted medRxiv a license to display the preprint in perpetuity.

It is made available under a CC-BY-NC-ND 4.0 International license .

47 efficacy on individuals under 20 years.

48

49 Interpretation

50 We presented the optimal vaccination strategy for Japan and South Korea. Comparing the

51 results of these countries demonstrates that not only the effective contact rates containing $q_{i}$

52 but also the age-demographics of current epidemic in Japan (dominance in 20s) and South

53 Korea (dominant cases over 50s) affect vaccine allocation strategy.

54 
medRxiv preprint doi: https://doi.org/10.1101/2021.04.16.21255649; this version posted April 20, 2021. The copyright holder for this preprint

\section{Introduction}

56 The pandemic of coronavirus disease 2019 (COVID-19), an infectious disease caused by

57 severe acute respiratory syndrome coronavirus 2 (SARS-CoV-2), is still ongoing in a rapid

58 and a widespread manner. The high transmissibility of SARS-CoV-2 might be attributed to its

59 route of transmission (respiratory) and its viral shedding pattern (peak viral loads at the

60 symptom onset). ${ }^{1,2}$ These characteristics hinder efficient public health control of COVID-19.

62 Therefore, COVID-19 vaccines are expected to be a game changer for ending this pandemic.

63 Several promising vaccines are under development or have received emergency use 64 authorisation in many countries including the United Kingdom (UK) and the United States $65(\mathrm{US}) .^{3-5}$

67 Vaccine supply, however, is expected to be limited in 2021. As of March 31, 2021, Japan 68 immunized 877,159 individuals $(0.7 \%)$ and South Korea immunized 852,202 individuals $69(1.6 \%)$ at least the first dose, which are far less proportions than countries in Europe and 70 America. ${ }^{6,7}$ Determination of who to prioritise for COVID-19 vaccination is an important 71 matter that plays a major role in curbing the growing burden of the disease.

73 Vaccinating the younger population, who have high contact rates, could lower the total

74 COVID-19 incidence, whereas targeting the elderly, who have high mortality rates, would

75 lower the death toll. ${ }^{8,9}$ Given the scarcity of vaccines, the World Health Organisation (WHO)

76 recommended to focus initially on direct reduction of mortality, and maintenance of most 
77 critical essential workers. ${ }^{10}$ Likewise, many countries including the European Union, UK,

78 and the US announced interim recommendations in which healthcare personnel, long-term

79 care facility residents, and elderly people with various age cut-offs were prioritised for

80 COVID-19 vaccination. ${ }^{11,12}$ By contrast, Indonesia plans to vaccinate working young adults

81 before the elderly. ${ }^{13}$ Indeed, the vaccination strategy could vary in countries, and the optimal

82 allocation strategy could be informed by modelling studies accounting for country-specific

83 characteristics.

85 Here, we constructed the modified Susceptible-Exposed-Infectious-Quarantine (SEIQ) model,

86 using the observed distributions of the latent period $(\mathrm{E} \rightarrow \mathrm{I})$ and the diagnostic delay $(\mathrm{I} \rightarrow \mathrm{Q})$,

87 along with the transmission onset distribution relative to the symptom onset. ${ }^{14}$ Bayesian

88 inference with Markov Chain Monte Carlo method was used for parameter estimation of age-

89 stratified force of infection $(\mathrm{S} \rightarrow \mathrm{E})$. By virtue of this realistic compartmental model, the

90 main objective of this study is to determine the optimal administration of COVID-19

91 vaccines, in both Japan and South Korea, in terms of reduction of (a) total incidence and (b)

92 the death toll. 
medRxiv preprint doi: https://doi.org/10.1101/2021.04.16.21255649; this version posted April 20, 2021. The copyright holder for this preprint

\section{Methods}

\section{Epidemiologic data}

96 The epidemiologic data consisted of COVID-19 reports provided by the Ministry of Health,

97 Labour and Welfare of Japan and the Ministry of Health and Welfare of South Korea. ${ }^{6,7}$ Both

98 governments report COVID-19 cases by 10-year age interval, diagnosed with SARS-CoV-2

99 polymerase chain reaction test. We could regard those numbers as real case numbers 100 according to the ascertainment levels close to $100 \%$ in Japan and South Korea, given the 101 baseline case-fatality ratio of $1.4 \% .^{15}$ The age-specific mortality ratios were also collected. ${ }^{6,7}$

\section{Demography and contact matrix}

104 Age-structured population data were obtained from the Statistics Bureau Japan and Statistics

105 Korea. ${ }^{16,17}$ We introduced contact matrices in our compartmental model, using the contact 106 survey data by Ibuka et al. for Japan, and projected contact matrix by Prem et al. for South 107 Korea. ${ }^{8,18}$ New contact matrix with 5-year age intervals was established for Japan from diary 108 data that included 4331 respondents using a bootstrap method. ${ }^{18,19}$

110 To capture the changes of contact patterns as a result of social distancing measures, we took 111 into account school closure policies and reduced contact rates at both work and other places 112 using Google mobility data. ${ }^{20-22}$ In Japan, most schools that had been temporarily closed 113 reopened on June 1, 2020, whereas in South Korea, school attendance has been capped at 114 two-thirds during national distancing level 1, one-thirds during level 2 (except for high 115 schools which remained 2/3), and remote learning only during level 3 throughout 2020 
116 (Figure 1).

118 Transmission model

119 What we could observe is the age-stratified (10-year interval) incidence of COVID-19. This 120 was made compatible to the contact matrix by dividing the incidence data in 5-year instead of 121 10-year age groups proportionally to demographic structure. From previous epidemiologic 122 studies, we know the (i) incubation period distribution, (ii) transmission onset distribution 123 relative to symptom onset, and the (iii) delay from symptom onset to diagnosis. ${ }^{14}$ The (iv) 124 latent period distribution could be derived from both incubation period and transmission onset distribution (Figure 2). In Japan and South Korea, individuals who have been diagnosed with COVID-19 are isolated immediately; thus, the confirmation date could be regarded as the date on which isolation had begun.

For those who eventually developed symptoms (Ipresym* $\rightarrow$ Isym), we could infer the individual's symptom onset relative to the diagnosed date using (iii). Then, we could successively infer transmission onset using (ii) and exposure date using (i).

133 For those who never developed any symptoms (Iasym), accounting for $16 \%$ of total infection

134 by a meta-analysis ${ }^{23}$, we assumed that their (iv) latent period distribution is the same as those 135 who developed symptoms. Also, we regard that the infectious period distribution for Iasym is 136 the same as the total infectiousness period of symptomatic cases as suggested. ${ }^{24}$ We suppose 137 that the Iasym is quarantined at random during the infectious period, and the relative 
medRxiv preprint doi: https://doi.org/10.1101/2021.04.16.21255649; this version posted April 20, 2021. The copyright holder for this preprint

(which was not certified by peer review) is the author/funder, who has granted medRxiv a license to display the preprint in perpetuity.

It is made available under a CC-BY-NC-ND 4.0 International license .

138 infectiousness of the Iasym is half of that of the others. ${ }^{24}$

139

140 Then, what is left to estimate is the age-stratified force of infection $(\mathrm{S} \rightarrow \mathrm{E})$. According to

141 Vynnycky and White, ${ }^{25}$ the force of infection $\lambda_{i}$ experienced by age group $i$ is:

$$
\lambda_{i}=\sum_{j} \beta_{i j} I_{j}
$$

142 Here, $\beta_{i j}$ is the rate at which susceptible in the age group $i$ and infectious individuals in the 143 age group $j$ come into effective contact per unit time, and $I_{j}$ is the number of infectious 144 individuals in the age group $j$. We further divide $\beta_{i j}$ into:

$$
\beta_{i j}=q_{i} \frac{\phi_{i j}}{N_{i}}
$$

145 Here, $q_{i}$ is the probability that a contact between a susceptible in age group $i$ and an 146 infectious person leads to infection, $\phi_{i j}$ is the number of contacts an individual of age group $147 j$ makes with those of age group $i$ per unit time, and $N_{i}$ is the number of individuals in age 148 group $i$. Since we know the contact matrix for Japan and South Korea, we could estimate $q_{i}$ 149 for both the countries. All analyses were conducted using the $R$ statistical software version 150 3.6.3. Detailed Bayesian inference methods are available in the Supplementary Method. Code 151 and data to reproduce the analyses are available as an $R$ package at 152 https://github.com/Hwichang/COVID-19-Vaccine-Prioritisation.

154 Japan and South Korea have similar epidemiological trends; (a) the import-driven first wave, 155 (b) domestic origin second wave closely related to nightlife clusters, ${ }^{26,27}$ and (c) the third 
medRxiv preprint doi: https://doi.org/10.1101/2021.04.16.21255649; this version posted April 20, 2021. The copyright holder for this preprint

(which was not certified by peer review) is the author/funder, who has granted medRxiv a license to display the preprint in perpetuity.

It is made available under a CC-BY-NC-ND 4.0 International license .

156

157

158

159

160

wave possibly enhanced by a seasonality factor (Figure 1). We used the third wave mainly for our simulation considering that this period could reflect the real characteristics of SARS-

CoV-2 transmission in each country not only excluding the importation factor, but also including the effects of seasonality similar to other respiratory viruses. Thus, the study period was set from October $15^{\text {th }}$ to December $25^{\text {th }}, 2020$, for Japan prior to the winter vacation, and from October $15^{\text {th }}$ to December $22^{\text {nd }}, 2020$, for South Korea prior to the "ban of gathering of five or more people". During the third wave, people in their 20s still constituted most of the confirmed cases in Japan following the second wave, whereas in South Korea, this shifted to those over 50 during the third wave.

\section{Vaccination scenarios}

Using the SEIQ model, we could calculate how many cases and deaths would arise without any intervention, including vaccination, after 2 weeks of the study period by means of forward projection. We set this as the baseline scenario and explored how to allocate COVID19 vaccines according to age groups, with stepwise increase in vaccine supply relative to the population size. Being vaccinated, the susceptible population in each age group would decrease, and our ultimate goal was to find the optimal distribution of vaccines to reduce COVID-19 cases and deaths.

\section{Sensitivity analysis}

Among model parameters, proportion of asymptomatic cases and vaccine efficacy were hypothesised values. We thus tried to vary those values with sensitivity analysis. For the 
178 proportion of asymptomatic cases, the meta-analysis showed that it ranged from $4 \%$ to $41 \%$,

179 and we varied the parameter accordingly from $4 \%$ to $40 \% .^{23}$ As far as vaccine efficacy was

180 concerned, we adopted the age-dependent COVID-19 vaccine efficacy with statistical

181 significance. ${ }^{4}$ Since there is a paucity of information on vaccine efficacy of children, we first

182 assumed the same efficacy as young adults, and further analysed the sensitivity with half

183 efficacy of children. Lastly, we assumed the COVID-19 vaccine efficacy against

184 asymptomatic infection as $70 \%$ across all analyses. ${ }^{28}$

186 Ethics approval

187 All the data used in this study were publicly available, and therefore were regarded exempt 188 from institutional review board assessment. 
medRxiv preprint doi: https://doi.org/10.1101/2021.04.16.21255649; this version posted April 20, 2021. The copyright holder for this preprint

(which was not certified by peer review) is the author/funder, who has granted medRxiv a license to display the preprint in perpetuity.

It is made available under a CC-BY-NC-ND 4.0 International license.

\section{Results}

\section{Model estimation}

192 The age-stratified probability $\left(q_{i}\right)$ that a susceptible person of age group $i$ acquires 193 infection given contact with an infectious person was estimated as in Figure 3. Both Japan 194 and South Korea showed similar trends of age-dependent increase. The lowest $q_{i}$ value was 195 seen in the age group of 5 to 10 years $(0 \cdot 0043,95 \%$ CI [0.0040-0.0045] in Japan and 0.0293, $19695 \%$ CI [0.0270-0.0316] in South Korea), and the highest value was seen in the age group of 197 over 75 years $(0 \cdot 1599,95 \%$ CI $[0 \cdot 1568-0 \cdot 1628]$ in Japan and $0 \cdot 1577$, 95\% CI [0.1518198 0.1637] in South Korea). The model parameters are summarised in Table 1.

\section{Vaccine allocation by age groups}

201 With a provision of $20 \%$ to $100 \%$ of COVID-19 vaccines, considering the population size of 202 Japan, the optimal vaccine allocation to reduce total case and death numbers are shown in 203 Figure 4A. With a provision of $20 \%$ to $100 \%$ of COVID-19 vaccines, considering the 204 population size of South Korea, the optimal vaccine allocation to reduce total case and death 205 numbers are shown in Figure 4B. The very first group to receive vaccination to reduce case 206 numbers is aged 20-35 years in Japan and aged over 60 years in South Korea. In the same 207 manner, the first group to receive vaccination to reduce the death toll is aged over 75 years in 208 both countries. 
medRxiv preprint doi: https://doi.org/10.1101/2021.04.16.21255649; this version posted April 20, 2021. The copyright holder for this preprint

(which was not certified by peer review) is the author/funder, who has granted medRxiv a license to display the preprint in perpetuity.

It is made available under a CC-BY-NC-ND 4.0 International license .

211 Assuming that there were no further intervention strategies including vaccination, during the

212 third wave, there might have been 75,767 cases and 1,046 deaths in Japan and 25,521 cases

213 and 529 deaths in South Korea in the following 2 weeks of the study period. With gradual

214 vaccination in both countries, the lowest number of cases and deaths are shown in Table 2.

\section{Sensitivity analysis}

217 Varying the proportion of asymptomatic cases from $4 \%$ to $40 \%$, vaccine priority groups were

218 not changed in terms of case and death reduction. Likewise, reducing the vaccine efficacy of

219 individuals under 20 years to $50 \%$ did not change the priority, either (Supplementary Figure

$2201)$.

221 
medRxiv preprint doi: https://doi.org/10.1101/2021.04.16.21255649; this version posted April 20, 2021. The copyright holder for this preprint (which was not certified by peer review) is the author/funder, who has granted medRxiv a license to display the preprint in perpetuity.

It is made available under a CC-BY-NC-ND 4.0 International license .

\section{Discussion}

223 Given the limited initial availability of COVID-19 vaccines, the prioritisation of individuals

224 for vaccination is of utmost importance to public health workers and policy makers. Based on

225 mathematical modelling, we hereby present estimates to inform the distribution of COVID-19

226 vaccines among different age groups, both in Japan and South Korea, with a stepwise

227 increase in vaccine supply. Applying the reported COVID-19 vaccine efficacy, ${ }^{4}$ the initial

228 target groups to reduce the total incidence were young adults aged 20-35 years in Japan and

229 individuals aged over 60 years in South Korea. We interpret that this difference might be

230 attributed to the different age-group distribution of COVID-19 cases between Japan

231 (dominance in 20s) and South Korea (dominance over 50s) during the third wave, since the

232 force of infection $\lambda_{i}$ is not only affected by $\beta_{i j}$, but also by $I_{j}$ which is the number of

233 infectious individuals in the age group. On the other hand, the target groups to reduce total

234 deaths were primarily focused on the elderly, aged over 75 years in both countries.

236 To achieve the best model of SARS-CoV-2 transmission, we constructed a compartmental

237 model based on a solid epidemiological investigation which could increase the reliability of

238 our study. ${ }^{6,714}$ The estimated age-stratified probability of transmission given contact $\left(q_{i}\right)$

239 revealed similar results with other studies showing that children have lower probability of

240 transmission given contact. ${ }^{29}$ However, it is yet to be elucidated whether children are less

241 susceptible to COVID-19 or they show fewer clinical symptoms than adults, or both. To

242 specify the relative impact of those factors, a well-designed national seroprevalence study

243 would be necessary. In Japan and South Korea, seroprevalence of SARS-CoV-2 specific

244 antibodies were measured in local regions including the capital city from May to June 2020, 
medRxiv preprint doi: https://doi.org/10.1101/2021.04.16.21255649; this version posted April 20, 2021. The copyright holder for this preprint

245 and the results ranged from $0.03 \%$ to $0.17 \%$ in Japan and $0.07 \%$ in South Korea. Owing to a

246 low seroprevalence in both countries, it was not appropriate to derive an answer to the above

247 question. Moreover, there is a caveat to interpret the $q_{i}$ results, since it could be affected by

248 contact numbers, $\phi_{i j}$. Japan showed much lower $q_{i}$ values for individuals aged below 10

249 years than South Korea, and we assumed that the different school closure policies could

250 explain the discrepancy; contrary to Japan, South Korea maintained restrictions on the

251 number of students in school and the $q_{i}$ might have decreased as low as Japan if it had not

252 regulated school attendance. In addition, previous studies suggested that older age might

253 contribute to vulnerability to COVID-19 infection, it is possible that biological aspects also

254 affect the value of $q_{i}$ then further investigation would be desirable in this area. ${ }^{30}$

There are several limitations to this study. First, although the contact matrix is the most

257 important variable in this model, we do not have empirical data for the current mixing

patterns. We tried to modify the existing prepandemic contact matrix to make it as realistic as

259 possible, but it might be insufficient to reflect reality. Besides, in the existing Japanese

260 contact matrix, the 20-29 year age group is marginally under-represented, and for South

261 Korean contact matrix, we had to adopt the estimated result, not the measured one, since

262 there was no available national survey data so far. ${ }^{8,18}$ Secondly, we did not take essential

263 worker status and co-morbidities into consideration for our model. Third, seasonality would

264 undoubtedly affect COVID-19 transmission, but it was hard to include this factor in our

265 model. Then, our estimation might not be sufficient for prediction in future seasons. Fourth,

266 the geographical heterogeneity was not considered in this study. In other words, differences in

267 frequency of contact between urban and rural areas could not be assessed here. Lastly, the 
medRxiv preprint doi: https://doi.org/10.1101/2021.04.16.21255649; this version posted April 20, 2021. The copyright holder for this preprint

(which was not certified by peer review) is the author/funder, who has granted medRxiv a license to display the preprint in perpetuity.

It is made available under a CC-BY-NC-ND 4.0 International license .

268

269

270

271

272

273

274

275

276

277

278

279

280

281

282

283

284

285

286 The authors declare that they have no known competing financial interests or personal

287 relationships that could have appeared to influence the work reported in this paper.

exact proportion of asymptomatic cases is still unelucidated. We adopted the results from a meta-analysis and further conducted a sensitivity analysis with variable ranges of asymptomatic proportion. ${ }^{23}$

Here, we present a realistic compartmental model for COVID-19 transmission based on the reliable epidemiological investigation conducted in two East Asian countries, Japan and South Korea. Furthermore, we provide the optimal distribution strategy of COVID-19 vaccines under limited vaccine supply in both countries. In short, the balance between agedependent effective contact rates and age-specific incidences should be considered for national vaccination strategy. We believe that this study could guide public health practitioners based on the solid mathematical model.

\section{Author Contributions:}

JYC, YK and ST conceived and design the study. JYC and ST collected study data. HJ and YK analysed the data and JYC, PB, NO, and ST interpreted the results. JYC and HJ wrote a draft of the manuscript. All authors critically reviewed and approved the final manuscript.

\section{Declaration of Interest:}


medRxiv preprint doi: https://doi.org/10.1101/2021.04.16.21255649; this version posted April 20, 2021. The copyright holder for this preprint (which was not certified by peer review) is the author/funder, who has granted medRxiv a license to display the preprint in perpetuity.

It is made available under a CC-BY-NC-ND 4.0 International license .

\section{Role of the funding source:}

290 This work was supported by the National Research Foundation of Korea (NRF) grant funded

291 by the Korea government (MSIT) (No. 2020R1A2C3A01003550) and JSPS KAKENHI,

292 Grant number 18K17369 and 20K10546.

293

294 Acknowledgements:

295 Japanese contact matrix data was kindly provided by Dr. Yoko Ibuka, Faculty of Economics,

296 Keio University. We would like to thank Editage (www.editage.co.kr) for English language 297 editing. 
medRxiv preprint doi: https://doi.org/10.1101/2021.04.16.21255649; this version posted April 20, 2021. The copyright holder for this preprint (which was not certified by peer review) is the author/funder, who has granted medRxiv a license to display the preprint in perpetuity.

It is made available under a CC-BY-NC-ND 4.0 International license .

\section{References:}

301 1. He X, Lau EHY, Wu $\mathrm{P}$, et al. Temporal dynamics in viral shedding and 302 transmissibility of COVID-19. Nat Med 2020; 26: 672-5.

303 2. Cevik M, Tate M, Lloyd O, Maraolo AE, Schafers J, Ho A. SARS-CoV-2, SARS-

$304 \mathrm{CoV}$, and MERS-CoV viral load dynamics, duration of viral shedding, and infectiousness: a 305 systematic review and meta-analysis. Lancet Microbe 2021; 2: e13-e22.

306 3. Voysey M, Clemens SAC, Madhi SA, et al. Safety and efficacy of the ChAdOx1 307 nCoV-19 vaccine (AZD1222) against SARS-CoV-2: an interim analysis of four randomised 308 controlled trials in Brazil, South Africa, and the UK. Lancet 2021; 397: 99-111.

309 4. Baden LR, El Sahly HM, Essink B, et al. Efficacy and safety of the mRNA-1273 310 SARS-CoV-2 vaccine. N Engl J Med 2021; 384: 403-16.

3115 Polack FP, Thomas SJ, Kitchin N, et al. Safety and efficacy of the BNT162b2 mRNA 312 COVID-19 vaccine. N Engl J Med 2020; 383: 2603-15.

313 6. Ministry of Health, Labour and Welfare of Japan Press Release January 2021. 314 https://www.mhlw.go.jp/stf/houdou/houdou_list_202101.html (accessed Mar 31, 2021).

3157 Ministry of health and welfare. Coronavirus Disease-19, Republic of Korea. 316 http://ncov.mohw.go.kr/ (accessed Mar 31, 2021).

317 8. Prem K, van Zandvoort K, Klepac P, et al. Projecting contact matrices in 177 318 geographical regions: an update and comparison with empirical data for the COVID-19 era. 319 medRxiv 2020. doi: https://doi.org/10.1101/2020.07.22.20159772

320 9. Yanez ND, Weiss NS, Romand J-A, Treggiari MM. COVID-19 mortality risk for 321 older men and women. BMC Public Health 2020; 20: 1742. 
medRxiv preprint doi: https://doi.org/10.1101/2021.04.16.21255649; this version posted April 20, 2021. The copyright holder for this preprint (which was not certified by peer review) is the author/funder, who has granted medRxiv a license to display the preprint in perpetuity.

It is made available under a CC-BY-NC-ND 4.0 International license .

322 10. World Health Organization Strategic Advisory Group of Experts on Immunization.

323 WHO SAGE Roadmap For Prioritizing Uses Of COVID-19 Vaccines In The Context Of

324 Limited Supply, Ver 1.1. 2020.

325 11. Dooling K, Marin M, Wallace M, et al. The Advisory Committee on Immunization

326 Practices' Updated Interim Recommendation for Allocation of COVID-19 Vaccine — United

327 States, December 2020. MMWR Morb Mortal Wkly Rep 2021; 69: 1657-60.

328 12. European Centre for Disease Prevention and Control. Overview of COVID-19 329 vaccination strategies and vaccine deployment plans in the EU/EEA and the UK. ECDC:

330 Stockholm; 2020.

331 13. Ministry of Communication and Information, Republic of Indonesia. These are the 332 stages of the Covid-19 vaccination that will be carried out. 333 https://kominfo.go.id/content/detail/31784/ini-tahapan-vaksinasi-covid-19-yang-akan-

334 dilakukan/0/berita (accessed Jan 10, 2021).

335 14. Chun JY, Baek G, Kim Y. Transmission onset distribution of COVID-19. Int J Infect

336 Dis 2020; 99: 403-7.

337 15. Russell TW, Golding N, Hellewell J, et al. Reconstructing the early global dynamics 338 of under-ascertained COVID-19 cases and infections. BMC Medicine 2020; 18(1): 332.

339 16. Statistics Bureau Japan. Portal Site of Official Statistics of Japan. 340 https://www.stat.go.jp/english/data/index.html (accessed Jan 10, 2021).

341 17. Korean Statistical Information Service. Population Projection for Korea. 342 https://kosis.kr/statisticsList/statisticsListIndex.do?menuId=M_01_01\&vwcd=MT_ZTITLE 343 \&parmTabId=M_01_01\#SelectStatsBoxDiv (accessed Jan 10, 2021). 
medRxiv preprint doi: https://doi.org/10.1101/2021.04.16.21255649; this version posted April 20, 2021. The copyright holder for this preprint (which was not certified by peer review) is the author/funder, who has granted medRxiv a license to display the preprint in perpetuity.

It is made available under a CC-BY-NC-ND 4.0 International license .

344 18. Ibuka Y, Ohkusa Y, Sugawara T, et al. Social contacts, vaccination decisions and 345 influenza in Japan. J Epidemiol Community Health 2016; 70: 162-7.

346 19. Funk S, Knapp JK, Lebo E, et al. Combining serological and contact data to derive 347 target immunity levels for achieving and maintaining measles elimination. BMC Med 2019;

$348 \quad$ 17: 180.

349 20. Ministry of Education, Culture, Sports, Science and Technology-Japan. Information 350

on

MEXT's

measures

against

COVID-19.

351 https://www.mext.go.jp/a_menu/coronavirus/index_00006.html (accessed Jan 31, 2021).

352 21. Ministry of Education, Republic of Korea. Remote learning and school opening 353 information.

354 https://www.moe.go.kr/sub/info.do?m=580201\&page=580201\&num=02\&s=moe $\quad($ accessed 355 Jan 10, 2021).

356 22. Google. COVID-19 Community Mobility Reports.

357 https://www.google.com/covid19/mobility/ (accessed Jan 10, 2021).

358 23. Byambasuren O, Cardona M, Bell K, Clark J, McLaws M-L, Glasziou P. Estimating 359 the extent of asymptomatic COVID-19 and its potential for community transmission: 360 systematic review and meta-analysis. J Assoc Med Microbiol Infect Dis Can 2020; 5: 223-34.

361 24. Davies NG, Kucharski AJ, Eggo RM, Gimma A, Edmunds WJ. Effects of non362 pharmaceutical interventions on COVID-19 cases, deaths, and demand for hospital services 363 in the UK: a modelling study. Lancet Public Health 2020; 5: e375-e85.

364 25. Vynnycky E, White R. An introduction to infectious disease modelling: OUP oxford; 3652010. 
medRxiv preprint doi: https://doi.org/10.1101/2021.04.16.21255649; this version posted April 20, 2021. The copyright holder for this preprint (which was not certified by peer review) is the author/funder, who has granted medRxiv a license to display the preprint in perpetuity. It is made available under a CC-BY-NC-ND 4.0 International license.

366 26. Takaya S, Tsuzuki S, Hayakawa K, et al. Nightlife clusters of coronavirus disease in 367 Tokyo between March and April 2020. Epidemiol Infect 2020; 148: e250.

368 27. Kang CR, Lee JY, Park Y, et al. Coronavirus disease exposure and spread from 369 nightclubs, South Korea. Emerg Infect Dis 2020; 26: 2499-501.

370 28. Tande AJ, Pollock BD, Shah ND, et al. Impact of the COVID-19 Vaccine on 371 Asymptomatic Infection Among Patients Undergoing Pre-Procedural COVID-19 Molecular 372 Screening. Clinical Infectious Diseases 2021.

373 29. Davies NG, Klepac P, Liu Y, Prem K, Jit M, Eggo RM. Age-dependent effects in the 374 transmission and control of COVID-19 epidemics. Nat Med 2020; 26(8): 1205-11.

375 30. Kuo CL, Pilling LC, Atkins JL, et al. Biological Aging Predicts Vulnerability to 376 COVID-19 Severity in UK Biobank Participants. J Gerontol A Biol Sci Med Sci 2021. 
medRxiv preprint doi: https://doi.org/10.1101/2021.04.16.21255649; this version posted April 20, 2021. The copyright holder for this preprint (which was not certified by peer review) is the author/funder, who has granted medRxiv a license to display the preprint in perpetuity.

It is made available under a CC-BY-NC-ND 4.0 International license .

378 Table 1. Model parameters.

\begin{tabular}{|c|c|c|}
\hline Parameter & Value & Ref \\
\hline Incubation period & Gamma $(\mu=4 \cdot 544, \mathrm{k}=1 / 0 \cdot 709)$ & 14 \\
\hline $\begin{array}{l}\text { Transmission } r \text { onset } \\
\text { relative to the symptom } \\
\text { onset }\end{array}$ & $-4+\operatorname{Gamma}(\mu=5 \cdot 266, \mathrm{k}=1 / 0 \cdot 8709)$ & 14 \\
\hline Latent period & $\begin{array}{l}\text { Incubation period }+ \text { Transmission onset relative to } \\
\text { symptom onset }\end{array}$ & 14 \\
\hline $\begin{array}{l}\text { Delays from symptom } \\
\text { onset to diagnosis }\end{array}$ & Empirical distribution from the raw data & 14 \\
\hline $\begin{array}{l}\text { Infectious period for } \\
\text { asymptomatic cases }\end{array}$ & $\operatorname{Gamma}(\mu=4, \mathrm{k}=4 / 5)$ & 24 \\
\hline $\begin{array}{l}\text { Proportion } \\
\text { asymptomatic cases }\end{array}$ & $16 \%$ & 23 \\
\hline $\begin{array}{l}\text { Relative infectiousness of } \\
\text { asymptomatic cases }\end{array}$ & $50 \%$ & 24 \\
\hline Age groups & $\begin{array}{l}{[0,5),[5,10),[10,15),[15,20),[20,25),[25,30),[30,35),} \\
{[35,40),[40,45),[45,50),[50,55),[55,60),[60,65),} \\
{[65,70),[70,75),[75,+)}\end{array}$ & \\
\hline $\begin{array}{l}\text { Vaccine efficacy against } \\
\text { symptomatic infection }\end{array}$ & $\begin{array}{l}0.95 \text { for individuals aged }<65 \text { years } \\
0.86 \text { for individuals aged } \geq 65 \text { years }\end{array}$ & 4 \\
\hline $\begin{array}{l}\text { Vaccine efficacy against } \\
\text { asymptomatic infection }\end{array}$ & $70 \%$ of above (same age dependent manner) & 28 \\
\hline Fatality ratio (Japan) & $\begin{array}{l}0,0,0,0,0,0,0,0,0 \cdot 001,0 \cdot 001,0 \cdot 003,0.003,0 \cdot 013 \text {, } \\
0.013,0 \cdot 044,0.095\end{array}$ & 6 \\
\hline $\begin{array}{l}\text { Fatality ratio (South } \\
\text { Korea) }\end{array}$ & $\begin{array}{l}0,0,0,0,0,0,0 \cdot 0006,0 \cdot 0006,0 \cdot 001,0 \cdot 001,0.0031 \\
0 \cdot 0031,0 \cdot 0134,0 \cdot 0134,0 \cdot 0651,0 \cdot 1543\end{array}$ & 7 \\
\hline
\end{tabular}


Table 2. The lowest expected number of COVID-19 cases and deaths at 2 weeks after the third wave by stepwise vaccine supply.

\begin{tabular}{r|llllll}
\hline \multicolumn{1}{l|}{ Nation } & Vaccine supply & & & & \\
\hline \multicolumn{1}{ll}{ Japan } & No Vaccine & $20 \%$ & $40 \%$ & $60 \%$ & $80 \%$ & $100 \%$ \\
\hline Cases & 75767 & 40273 & 22870 & 13120 & 7266 & 3468 \\
$($ Range*) & $(72917-79759)$ & $(38813-41777)$ & $(22091-23683)$ & $(12675-13464)$ & $(6956-7437)$ & $(3404-3567)$ \\
Deaths & 1046 & 306 & 153 & 117 & 86 & 76 \\
$($ Range*) & $(1007-1084)$ & $(293-317)$ & $(152-159)$ & $(110-118)$ & $(83-93)$ & $(74-78)$ \\
\hline South Korea & No Vaccine & $20 \%$ & $40 \%$ & $60 \%$ & $80 \%$ & $100 \%$ \\
\hline Cases & 25521 & 16090 & 9923 & 5634 & 2558 & 1059 \\
$($ Range*) & $(23468-27774)$ & $(14830-17469)$ & $(9169-10749)$ & $(5218-6035)$ & $(2416-2711)$ & $(1002-1102)$ \\
Deaths & 529 & 94 & 67 & 47 & 38 & 33 \\
$($ Range*) & $(488-572)$ & $(88-103)$ & $(62-68)$ & $(45-49)$ & $(35-39)$ & $(31-34)$ \\
\hline
\end{tabular}

* Range was calculated based on the $95 \%$ Confidence interval of $q_{i}$ values. 
medRxiv preprint doi: https://doi.org/10.1101/2021.04.16.21255649; this version posted April 20, 2021. The copyright holder for this preprint

(which was not certified by peer review) is the author/funder, who has granted medRxiv a license to display the preprint in perpetuity.

It is made available under a CC-BY-NC-ND 4.0 International license .

382 Figure legends

383

384 Figure 1. Epidemic curve and national intervention in (A) Japan and (B) South Korea.

385

386 Figure 2. A schematic plot of different time periods of the transmission of SARS-CoV-2.

387

388 Figure 3. The age-stratified probability of transmission given contact $\left(q_{i}\right)$ of COVID38919 in (A) Japan and (B) South Korea.

390 As a sensitivity analysis, the $q_{i}$ values with varying proportions of asymptomatic cases from $3914 \%$ to $40 \%$ were presented together.

392

Figure 4. The optimal allocation strategy of COVID-19 vaccines according to age in (A) 394 Japan and (B) South Korea, in terms of case and death reduction.

395

396 Supplementary figure 1. The optimal allocation strategy of COVID-19 vaccines 397 according to age in Japan and South Korea with varying proportions of asymptomatic 398 cases and vaccine efficacy.

399

400 
medRxiv preprint doi: https://doi.org/10.1101/2021.04.16.21255649; this version posted April 20, 2021. The copyright holder for this preprint

(which was not certified by peer review) is the author/funder, who has granted medRxiv a license to display the preprint in perpetuity.

It is made available under a CC-BY-NC-ND 4.0 International license .

\section{$401 \quad$ Research in context}

\section{Evidence before this study}

403 We searched PubMed and MedRxiv for research articles published in English from database 404 inception until March 11, 2021, with the keywords "SARS-CoV-2", "COVID-19", "Vaccine", 405 "Immunization," "Distribution", "Allocation", and "Mathematical model". We found several 406 articles analysing the optimal distribution of COVID-19 vaccines fitted to each nation's 407 characteristics, notably in the US, UK, Germany, India, and South Korea. However, we 408 identified no research identifying age-specific force of infection to COVID-19 in East Asia, 409 further suggesting the optimal vaccination policy upon the mathematical model.

\section{Added value of this study}

412 Our study combined solid epidemiological data from Japan and South Korea and built the 413 reliable compartment model for SARS-CoV-2 transmission. Using the age-specific incidence 414 of COVID-19, we could estimate the age-stratified probability of transmission given contact 415 by Bayesian inference method, which was incorporated into the compartment model. By 416 virtue of this model, we could evaluate the effects of vaccine distribution scenarios by age in 417 terms of case and death reduction.

\section{Implications of all the available evidence}

Fortunately, safe and effective COVID-19 vaccines have been developed within an unprecedented period. For now, how to implement vaccination most effectively is of utmost importance. Here, we suggest the vaccine prioritisation strategy in Japan and South Korea, 
A

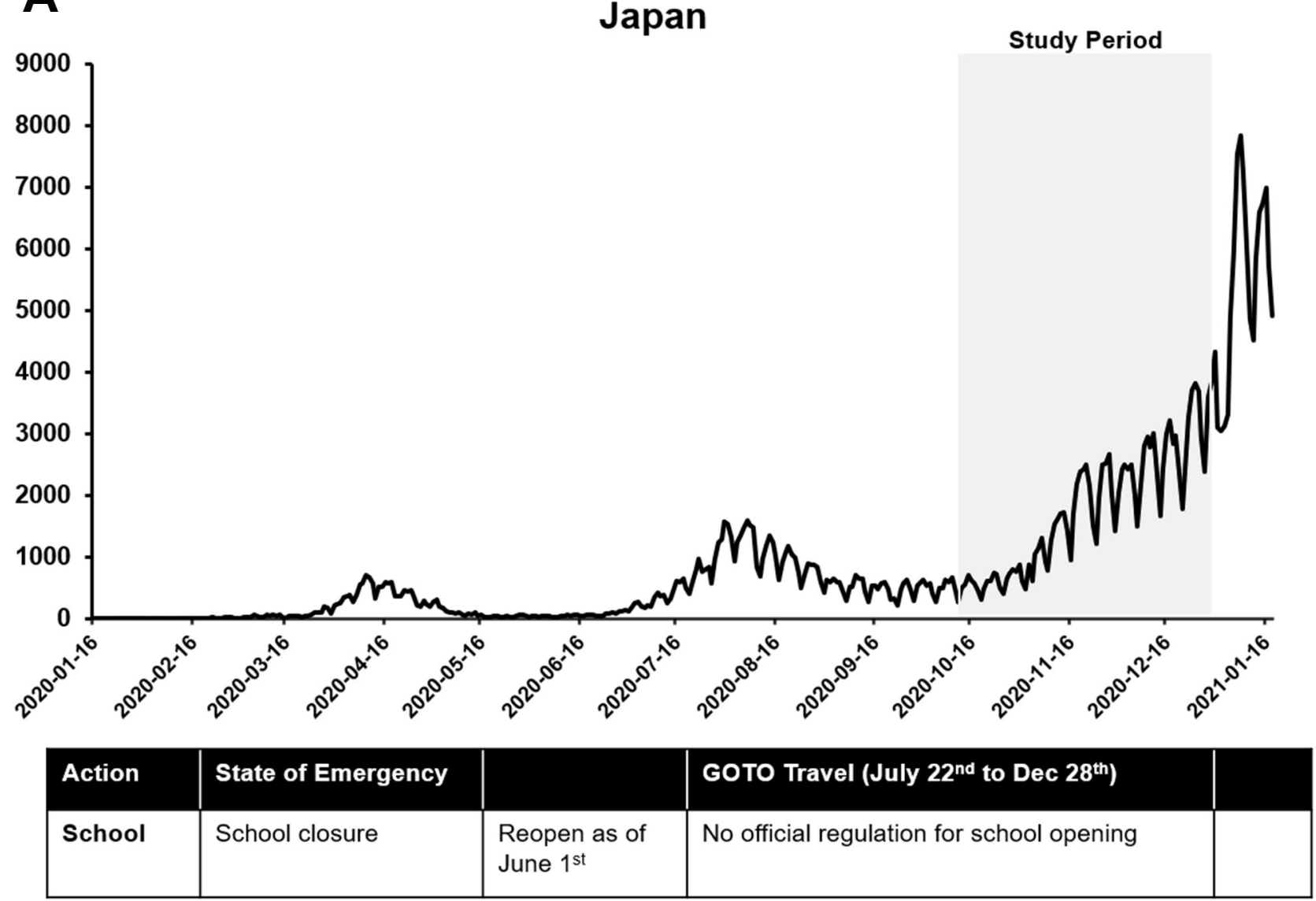

B

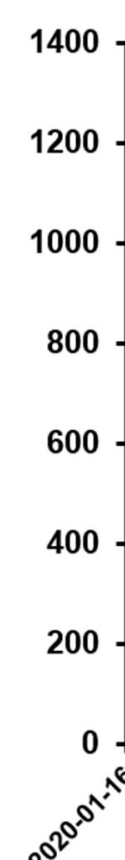

$\left.\begin{array}{l}1400 \\ 1200 \\ 1000 \\ 800 \\ 600 \\ 400 \\ 200 \\ 0\end{array}\right]$
South Korea

Study Period
Social distancing policy as of $28^{\text {th }}$ June School 


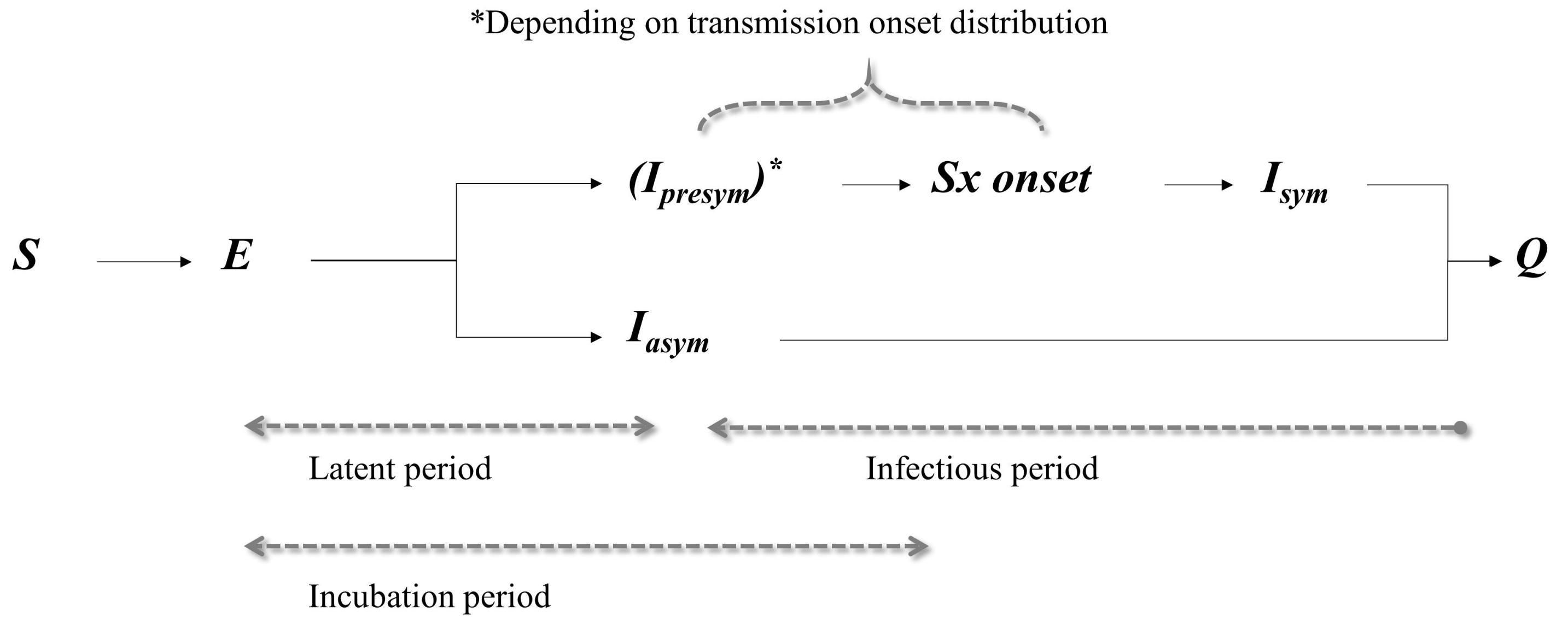


A

Japan

$\multimap$ Asym(4\%)

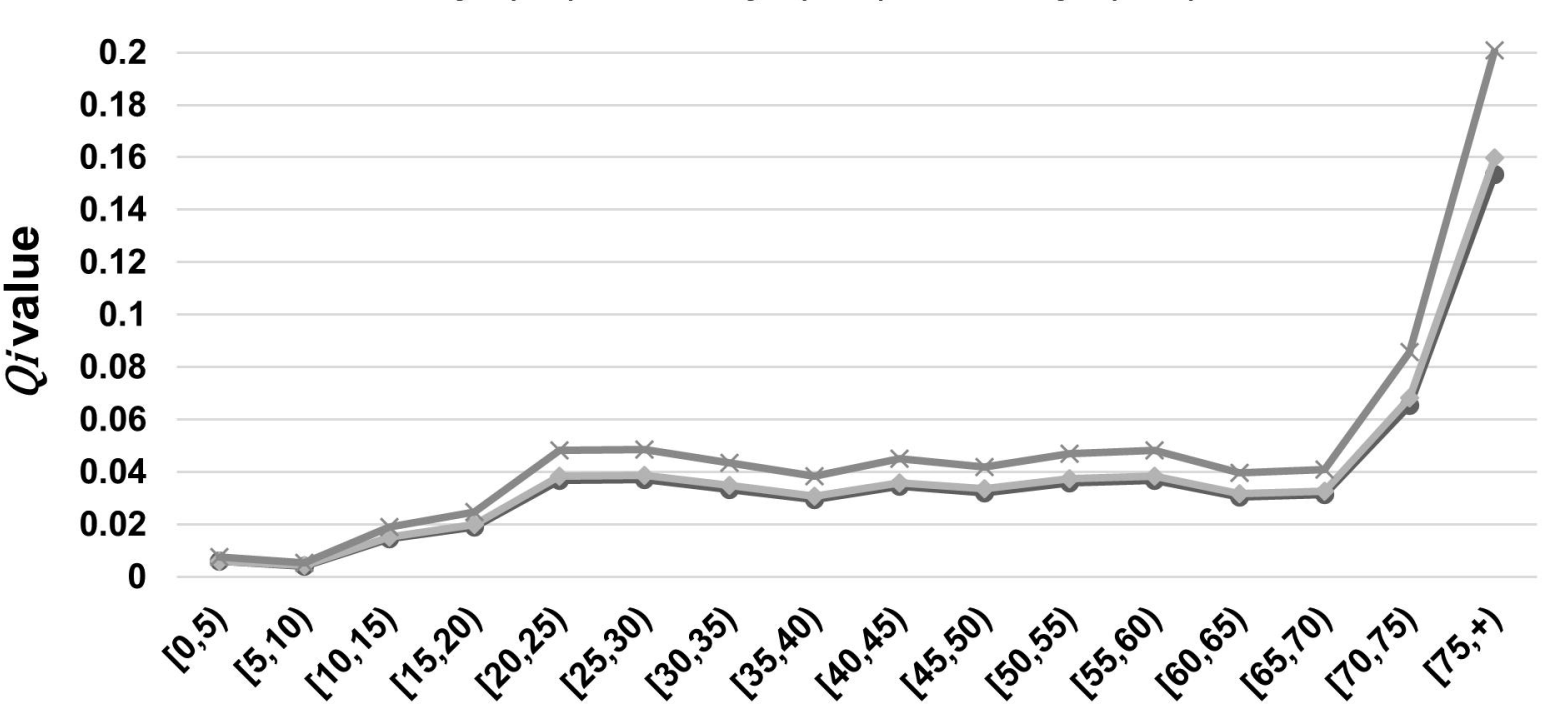

Age group (i)
B

South Korea

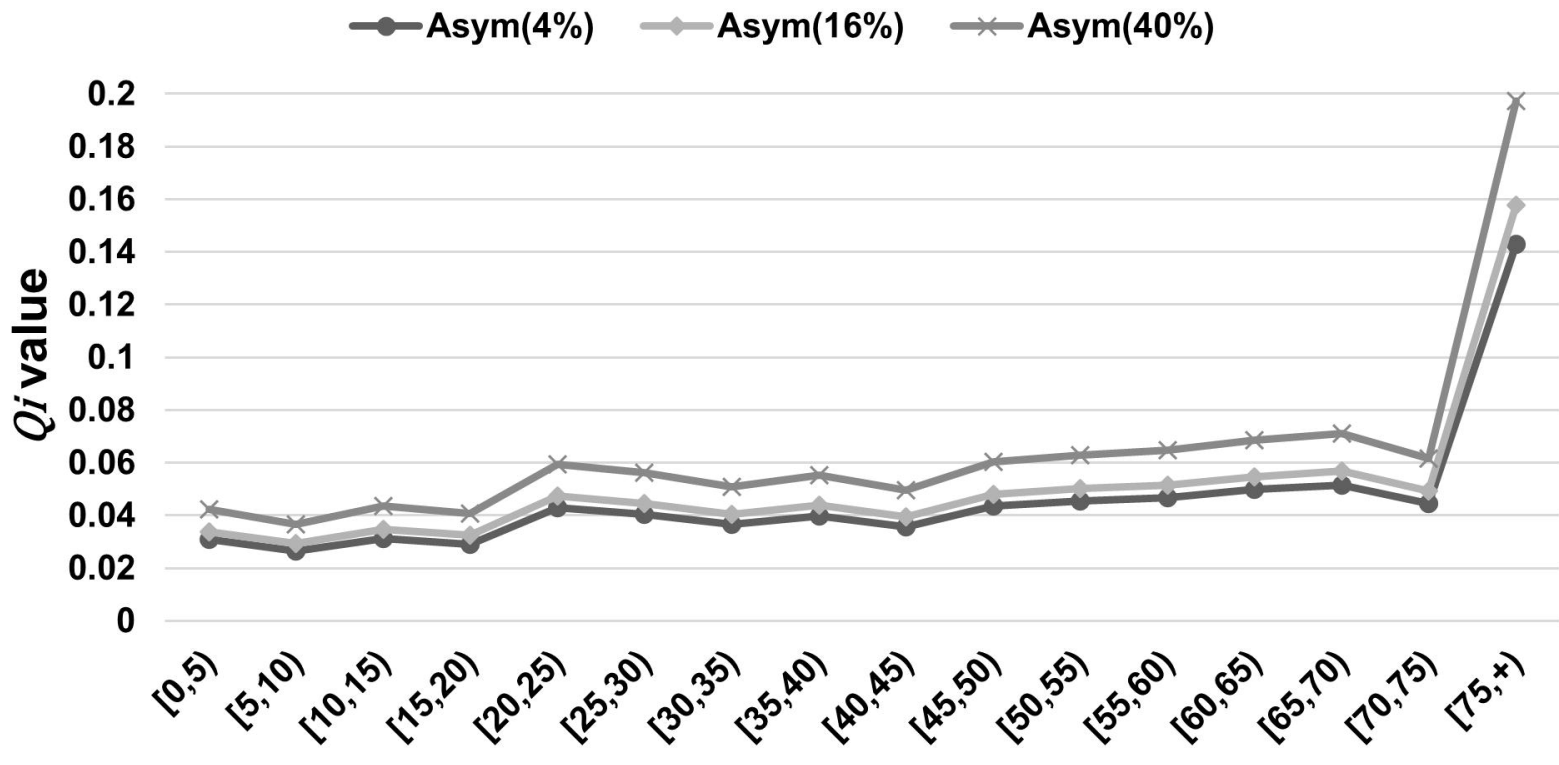

Age group (i) 
A

Japan

To reduce cases

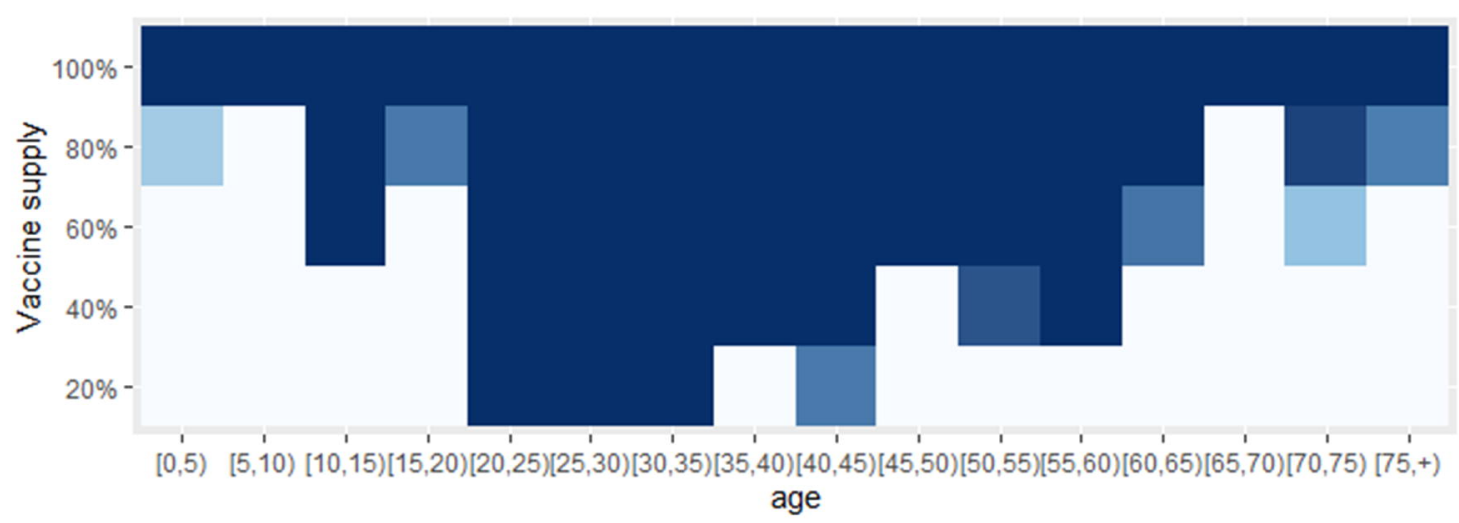

To reduce deaths

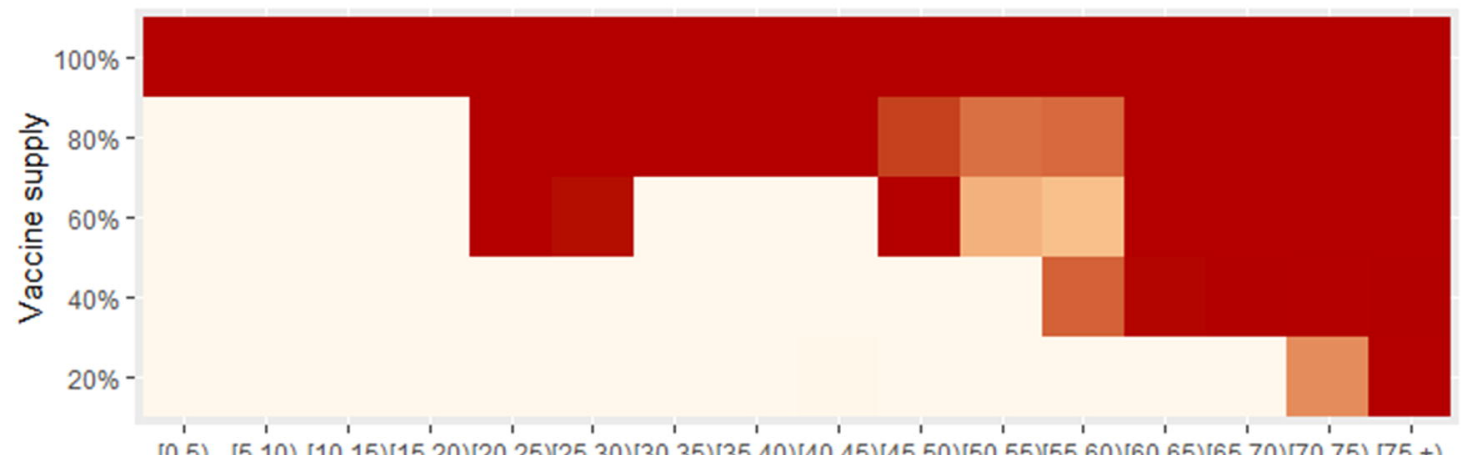

$[0,5)[5,10)[10,15)[15,20)[20,25)[25,30)[30,35)[35,40)[40,45)[45,50)[50,55)[55,60)[60,65)[65,70)[70,75)[75,+)$ age
B

\section{South Korea}
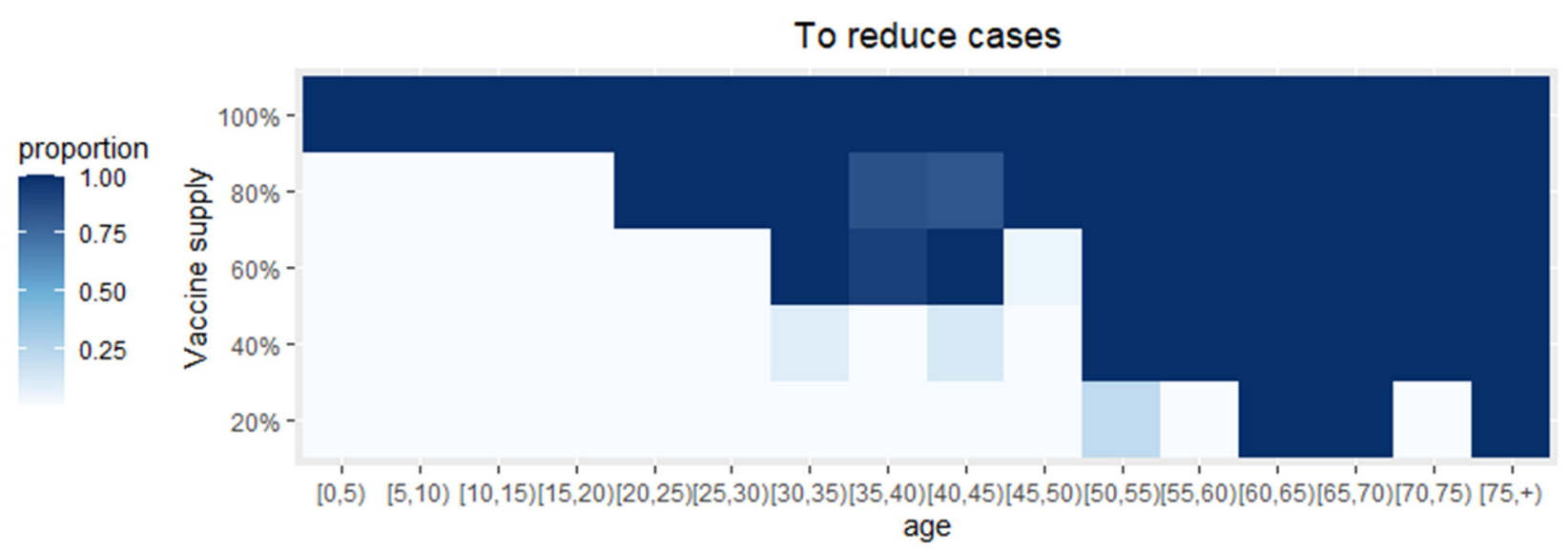

proportion

1.00

$-0.75$

0.50

0.25 age

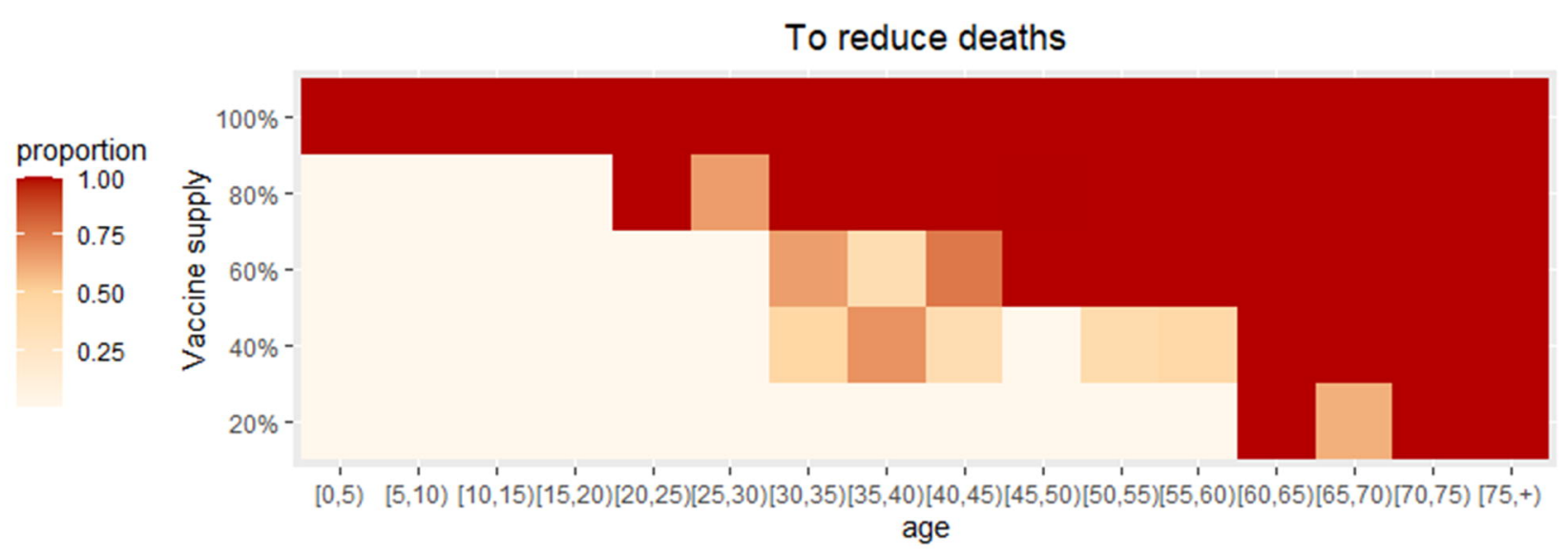

proportion

$-0.75$

0.50

0.25 